\title{
Volatility Transmission between Oil and LME Futures
}

\author{
Jaehwan Park \\ Correspondence: An analyst at the Public Procurement Service in Daejeon, Korea. \\ Received: December 18, 2017 \\ Accepted: January 15, $2018 \quad$ Available online: January 21, 2018 \\ doi:10.11114/aef.v5i2.2944 \\ URL: https://doi.org/10.11114/aef.v5i2.2944
}

\begin{abstract}
This paper investigates the volatility transmission between oil and base metals to assess the possibility of hedge strategy across commodity markets. In order to identify the volatility linkage of oil to the base metals, the bivariate GARCH model is applied using daily returns data period over 2000-2016. It is found that evidence of volatility transmission between oil and base metals is somewhat strong with a $1 \%$ significant level. This result suggests the investment idea of commodity hedging strategy of cross-market is important.
\end{abstract}

Keywords: volatility transmission, univariate GARCH, bivariate GARCH

\section{Introduction}

A base metal refers to industrial metals or non-ferrous metals, which are mostly used in durables goods' manufacturing process. The industrial metals mean for widely utilizing in economic activity, so that those volume growth implies the state of manufacturing business cycle (Hammoudeh \& Yuan, 2008). The oil, which is the key indicator in global commodity market, plays in the important role of the global economy and associated business cycles. Ratti \& Vespignani (2013) showed that the effect of an unanticipated supply shock on global oil production is very persistent and highly significant. They pointed out that the historical contributions of shocks in global real aggregate demand to real oil prices are of comparable size. Both oil and base metals futures markets have been attracted commodity funds such as CTAs (Commodity Trading Advisors) and even some hedge funds.

Ewing \& Malik (2013) examined the linkage that might exist between the volatilities in oil and gold in a way of the volatility dynamics between two major commodities to support the idea of cross-market hedging. They found strong evidence of significant transmission of volatilities between in these asset prices. Given that Ewing \& Malik (2013) result, the question arises of whether there has been volatility transmission from oil prices to base metals. In particular, oil markets often trigger a cost-push in inflation front. Classical macroeconomic theory suggests higher oil prices generate upward pressure in inflation (Hooker, 2002). The role of oil prices can possibly link to other commodity outputs and even capacity utilization ratio in manufacturing industry. Wu et al. (2011) found statistically significant volatility spillovers from oil prices to corn futures prices ${ }^{1}$, which revealed somewhat time-varying. Oil prices are also complements and substitutes in consumption, and inputs in production of others (Hammoudeh \& Yuan, 2008). While Ewing \& Malik (2013) focused on gold of inflation hedge characteristics, this paper concentrates on base metals of industry activity itself, paying attention to which volatility in base metals prices impacted by external shocks from oil prices.

This paper studies the volatility dynamics of oil and $\mathrm{LME}^{2}$ futures to identify the statistical linkage between the volatilities in base metals prices and oil prices using daily data from January 4, 2000 to December 30, 2016. The reason for analyzing the period after 2000 is because commodities were first considered as an alternative asset class in the asset management industry starting in 2000. (Cheng \& Xiong, 2014). This paper employs univariate and bivariate GARCH

\footnotetext{
${ }^{1} \mathrm{Wu}$ et al. (2011) pointed out that after the Energy Policy Act of 2005 corn prices had coupling with oil prices as the ethanol/gasoline consumption ratio reached a critical level due mainly to biofuel energy.

${ }^{2}$ The LME (London Metal Exchange) is the world's largest futures exchange in metal industry, which deals with base metals and provides spot (cash), futures (3M), and various option contracts for the six base metals. The LME address daily rolling three-month (3M) futures contracts that are different from those in other commodity markets, which are based on monthly prompt dates. (Park \& Lim, 2018) The LME is traded electronically but also traded through the open outcry. These characteristics are somewhat different from other asset markets, which can possibly impact the LME's volatility process (Figuerola-Ferretti \& Gilbert, 2008).
} 
model to examine volatility dynamics of base metals and oil futures. The empirical results suggest LME futures market volatility statistically link to oil futures market volatility.

This paper is organized as follows. Section 2 reviews the literature on the volatility of commodity futures market. Section 3 presents the empirical methodology introducing the univarate and bivariate GARCH model. Section 4 reports empirical results. The summary and implication are in Section 5.

\section{Literature Review}

Commodity price volatility is a crucial element in option pricing formulas for futures contracts and financial market risk assessment as a futures market valuation tool. Haigh \& Holt (2002) investigated oil futures market volatility spillovers between markets (crude oil, unleaded gasoline and heating oil) using multivariate GARCH model. They found somewhat significant reductions in uncertainty, when the volatility spillovers between markets were considered. Indeed, they presented that incorporating realistic assumptions regarding to co-movement of prices directly into the hedging strategy yielded substantial rewards in terms of risk reduction. Malik \& Hammoudeh (2007) found significant volatility and shock transmission among US equity, Gulf equity and oil markets through a multivariate GARCH technique. Using univariate GARCH models Ewing \& Malik (2010) revealed that oil shocks had a strong initial impact on volatility but dissipate very quickly under structural breaks. They concluded that the behavior of volatility in oil prices was important for derivative valuation and hedging decisions.

Batten \& Lucey (2010) reported the volatility structure of gold futures using intraday data with GARCH methodology and showed significant variation in volatility across the trading day on NYMEX (New York Mercantile Exchange), although volatility was slightly positively correlated with volume. Wu et al. (2011) found strong evidence of significant spillovers from oil prices to corn futures prices. They found that corn markets had become far more connected to oil markets after the introduction of the Energy Policy Act of 2005. Since then US biofuel production had gone through a rapid expansion in response to higher energy prices. They showed that oil prices transmitted positive volatility spillovers into corn prices, so that movements in corn prices were more energy-price-driven, as long as the ethanol-gasoline consumption ratio exceeded a critical level. Within this condition, the cross-hedging strategy between corn and oil provided slightly better hedging performance compared with traditional hedging in corn futures markets alone.

LME market front, few studies exhibited market volatility. Figuerrola-Ferretti \& Gilbert (2008) considered dynamic representation of spot and three-month aluminum and copper volatilities. Using bivariate FIGARCH model, they showed that spot and three-month aluminum and copper volatilities followed long memory process, but no evidence that the volatilities processes were fractionally cointegrated. Park \& Lim (2018) examined whether the price volatility of the LME changed within a sample period (January 2000-June 2016) to check the possibility of time varying volatility. They reported that the LME's volatility was somewhat larger post-crisis compared to pre-crisis for all base metals except nickel. They argued that somewhat serious inflow of investment money to the LME futures market had substantially changed volatility pattern.

\section{Methodology}

\subsection{Univariate GARCH Model}

This paper applies the GARCH $(1,1)$ model given as:

$$
\begin{gathered}
\mathrm{R}_{\mathrm{t}}=\mu+\rho \mathrm{R}_{\mathrm{t}-1}+\varepsilon_{\mathrm{t}} \\
\mathrm{h}_{\mathrm{t}}=\omega+\alpha \varepsilon_{\mathrm{t}-1}^{2}+\beta \mathrm{h}_{\mathrm{t}-1}
\end{gathered}
$$

where $R_{t}$ means the corresponding oil or base metals return series. $\varepsilon_{t}$ is normally distributed white noise and $h_{t}$ represents the conditional variance, which depends on the mean volatility level $(\omega)$, the noise from previous period $\left(\varepsilon_{\mathrm{t}-1}^{2}\right)$, and the conditional variance from the previous period $\left(\mathrm{h}_{\mathrm{t}-1}\right)$. The coefficients of $\alpha$ and $\beta$ imply that noise from previous period and volatility from previous period respectively. The sum of $\alpha$ and $\beta$ suggests the level of volatility persistence. Notice that this sum is close to one as long as high frequency data is used, that implies shocks are somewhat highly persistent.

\subsection{Bivariate GARCH Model}

The bivariate GARCH $(1,1)$ model given as:

$$
\mathrm{H}_{\mathrm{t}}=\mathrm{C}^{\prime} \mathrm{C}+\mathrm{B}^{\prime} \mathrm{H}_{\mathrm{t}-1} \mathrm{~B}+\mathrm{A}^{\prime} \varepsilon_{\mathrm{t}-1} \varepsilon_{\mathrm{t}-1}^{\prime} \mathrm{A}
$$

where $\mathrm{C}$ is a $2 \times 2$ lower triangular matrix with three parameters and $\mathrm{B}$ is a $2 \times 2$ square matrix of parameters, which implies the current levels of conditional variances and past conditional variance respectively. A is a $2 \times 2$ square matrix of parameters, which represents how conditional variances are affected with past squared errors.

Rewritten equation (3) in terms of each equation gives: 


$$
\begin{gathered}
\mathrm{h}_{11, \mathrm{t}}=\mathrm{c}_{11}^{2}+\mathrm{b}_{11}^{2} \mathrm{~h}_{11, \mathrm{t}-1}+2 \mathrm{~b}_{11} \mathrm{~b}_{21} \mathrm{~h}_{12, \mathrm{t}-1}+\mathrm{b}_{21}^{2} \mathrm{~h}_{22, \mathrm{t}-1}+\mathrm{a}_{11}^{2} \varepsilon_{1, \mathrm{t}-1}^{2}+2 \mathrm{a}_{11} \mathrm{a}_{21} \varepsilon_{1, \mathrm{t}-1} \varepsilon_{2, \mathrm{t}-1}+\mathrm{a}_{21}^{2} \varepsilon_{2, \mathrm{t}-1}^{2} \\
\mathrm{~h}_{22, \mathrm{t}}=\mathrm{c}_{12}^{2}+\mathrm{c}_{22}^{2}+\mathrm{b}_{12}^{2} \mathrm{~h}_{11, \mathrm{t}-1}+2 \mathrm{~b}_{12} \mathrm{~b}_{22} \mathrm{~h}_{12, \mathrm{t}-1}+\mathrm{b}_{22}^{2} \mathrm{~h}_{22, \mathrm{t}-1}+\mathrm{a}_{12}^{2} \varepsilon_{1, \mathrm{t}-1}^{2}+2 \mathrm{a}_{12} \mathrm{a}_{22} \varepsilon_{1, \mathrm{t}-1} \varepsilon_{2, \mathrm{t}-1}+\mathrm{a}_{22}^{2} \varepsilon_{2, \mathrm{t}-1}^{2}
\end{gathered}
$$

Equation (4) and equation (5) represent that the conditional variances are transmitted through the two time series each other, which imply how shocks affect across oil and base metals over time. (Bollerslev \& Wooldridge, 1992)

\section{Empirical Results}

\subsection{Data}

This paper uses daily futures prices for oil (denote oi) from January 4, 2000 to December 30, 2016, which trades on NYMEX of the three-month futures contracts which is the benchmark nearest expiration contract on the market. Prices for oil futures data obtained from Reuters. Notice that the three-month futures contracts are the most liquid, so that futures prices are more responsive to the market information and future expectation. The LME data are used for base metals, which include copper (cu), aluminum (al), lead (pb), zinc (zn), tin (sn), and nickel (ni). The benchmark futures price for base metals is the expiration contract of 3 months (3M), which is also obtained from Reuters over same period. Hence, this study utilizes daily data for the closing three-month futures prices.

Table 1 reports the descriptive statistics of daily log returns data over the sample period. The six base metals returns series are somewhat leptokurtic. The skewness and kurtosis measures show that the price change distributions are asymmetric and fat-tailed (excess kurtosis). The volatilities, given in the second row of Table 1, correspond to the standard deviation of daily log returns over the period and that of nickel is the largest but that of aluminum is the lowest.

Table 1. Summary Statistics

\begin{tabular}{l|l|l|l|l|l|l|l}
\hline & oi & $\mathrm{cu}$ & $\mathrm{al}$ & $\mathrm{pb}$ & $\mathrm{zn}$ & $\mathrm{sn}$ & $\mathrm{ni}$ \\
\hline Mean & 0.00023 & 0.000198 & -0.000028 & 0.000268 & 0.000084 & 0.000270 & 0.000085 \\
Standard deviation & 0.021232 & 0.016854 & 0.013199 & 0.200009 & 0.018569 & 0.017278 & 0.023250 \\
Skewness & -0.120939 & -0.095907 & -0.219071 & -0.237140 & -0.189190 & -0.176257 & -0.142131 \\
Maximum & 0.121150 & 0.118804 & 0.059130 & 0.126751 & 0.096563 & 0.142533 & 0.130603 \\
Minimum & -0.121607 & -0.104002 & -0.074373 & -0.128495 & -0.108322 & -0.114346 & -0.181060 \\
Kurtosis & 5.559868 & 7.471589 & 5.189371 & 6.74522 & 5.961389 & 9.301117 & 6.5654 \\
Jarque-Bera & 256.69 & 417.16 & 241.12 & 390.85 & 308.98 & 552.79 & 352.37 \\
& $(0.000)$ & $(0.000)$ & $(0.000)$ & $(0.000)$ & $(0.000)$ & $(0.000)$ & $(0.000)$ \\
\hline
\end{tabular}

Note: The total observation contains 4,030 obs. (January 4, 2000 December 30, 2016; daily data). The natural logarithm data are applied in returns calculations.

Jarque-Bera statistic is for checking normal distribution. Actual probability values are in parentheses.

The analysis of Pearson correlation coefficients between oil and base metals over the period reports in Table 2, in terms of providing some preliminary analysis. Ewing \& Malik (2013) found that the correlation between both the returns series of oil and gold was 0.20 . It is found that the correlation between both the returns series of oil and base metals futures over sample period is somewhat higher of range between 0.25 of tin and 0.35 of copper. This higher correlation may explain the possibility of co-movement each other and important degrees of industrial usages. Notice that Tang \& Xiong (2012) found that the return correlation among major commodities in recent years increased. They showed that oil had low return correlations with cotton and live cattle before 2004 and that the correlations rose to 0.5 since then due mainly to financialization by major commodity funds. Silvennoinen \& Thorp (2013) reported that financial activity by institutional investors and exchange traded funds (ETFs) in commodity securities markets had grown substantially since 2000. In particular, rises in oil prices have influenced increases in base metals outputs, which affect base metals returns and volatility through this simple transmission channels.

Table 2. Correlation Matrix

\begin{tabular}{l|lllllll}
\hline & oi & cu & al & pb & zn & sn & ni \\
\hline oi & 1.00 & & & & & & \\
cu & 0.35 & 1.00 & & & & & \\
al & 0.31 & 0.71 & 1.00 & & & & \\
pb & 0.28 & 0.64 & 0.56 & 1.00 & & & \\
zn & 0.27 & 0.73 & 0.66 & 0.67 & 1.00 & & \\
sn & 0.25 & 0.51 & 0.44 & 0.45 & 0.46 & 1.00 & \\
ni & 0.26 & 0.60 & 0.52 & 0.50 & 0.56 & 0.45 & 1.00 \\
\hline
\end{tabular}

Note: The sample consists of 4,030 observations. All correlation coefficients of oil and base metals reveal statistical significance at least at the $1 \%$ level except zinc. 
Figure 1 shows the daily price behavior in oil prices and copper prices over the sample period. The figure implies synchronized boom and bust cycles driven by the Chinese massive infra investment and the global financial crisis by Lehman Brothers bankruptcy with similar pattern. Once again, both commodity prices surged until mid-2011 thanks to the unconventional monetary policy of the FRB (Federal Reserve Board)'s QE (Quantitative Easing) and fell upto early 2016 due mainly to rise in supply by major global mining companies such as Glencore, Rio Tinto and BHP Billiton etc. Park \& Lim (2018) presented that the price fluctuation of lead is largest among six base metals, while the changes in aluminum prices are lowest within similar data period (January 2000-June 2016).

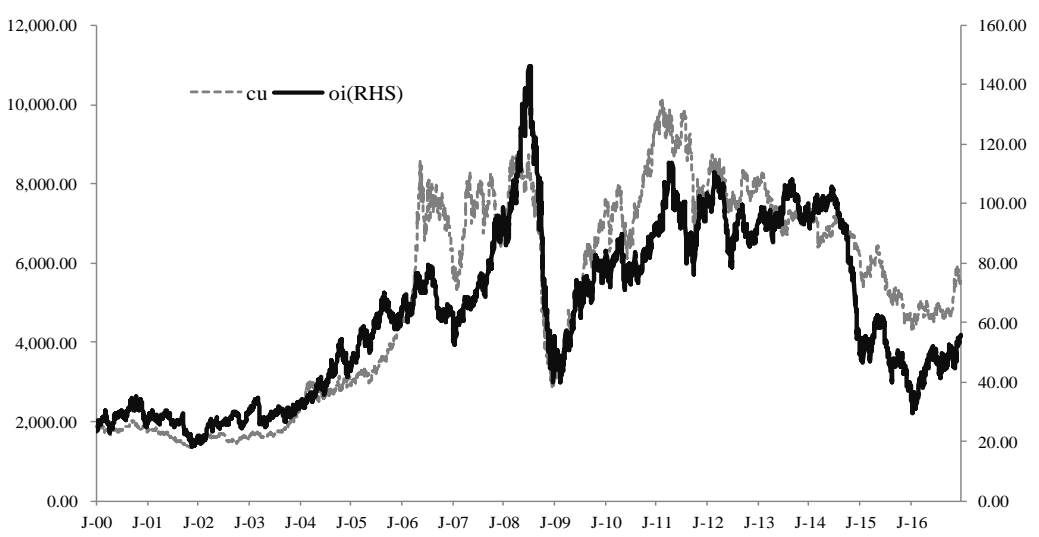

Figure 1. Plot of oil and copper prices

Description: The solid line is oil prices (NYMEX) over the January 4, 2000 and December 30, 2016 of 17 years, while the dotted line is copper prices (LME)

\subsection{Empirical Results}

Results obtain from estimation of univariate GARCH model report in Table 3. It is found that key parameters to be statistically significant with $1 \%$ significance level, which means the price volatilities of both oil and base metals are somewhat time-varying. The volatility persistent reveals high level. The robust mean-revision phenomenon finds at copper with 5\% significance level, while lead reveals somewhat positive coefficient $\rho$ with 5\% significance level. 
Table 3. Univariate GARCH $(1,1)$ Estimation

\begin{tabular}{|c|c|c|c|c|c|}
\hline & & coefficient & S.E. & Z-statistic & p-value \\
\hline \multirow{5}{*}{ oi } & $\mu$ & 0.0006 & 0.0027 & 2.34 & 0.019 \\
\hline & $\rho$ & -0.0255 & 0.0160 & -1.60 & 0.111 \\
\hline & $\omega$ & 0.000001 & 0.0000002 & 3.65 & 0.000 \\
\hline & $\alpha$ & 0.1274 & 0.0111 & 11.43 & 0.000 \\
\hline & $\beta$ & 0.8549 & 0.0142 & 60.08 & 0.000 \\
\hline \multirow{5}{*}{$\mathrm{cu}$} & $\mu$ & 0.0002 & 0.0002 & 1.16 & 0.245 \\
\hline & $\rho$ & -0.0395 & 0.0178 & -2.21 & 0.027 \\
\hline & $\omega$ & 0.000004 & 0.000001 & 3.27 & 0.001 \\
\hline & $\alpha$ & 0.1257 & 0.0083 & 15.02 & 0.000 \\
\hline & $\beta$ & 0.8623 & 0.0106 & 81.27 & 0.000 \\
\hline \multirow{5}{*}{ al } & $\mu$ & 0.000004 & 0.0001 & 0.02 & 0.982 \\
\hline & $\rho$ & -0.0318 & 0.0170 & -1.86 & 0.062 \\
\hline & $\omega$ & 0.000001 & 0.0000001 & 1.43 & 0.153 \\
\hline & $\alpha$ & 0.0787 & 0.0082 & 9.51 & 0.000 \\
\hline & $\beta$ & 0.9150 & 0.0108 & 84.55 & 0.000 \\
\hline \multirow{5}{*}{$\mathrm{pb}$} & $\mu$ & 0.0003 & 0.0002 & 1.42 & 0.136 \\
\hline & $\rho$ & 0.0352 & 0.0165 & 2.13 & 0.033 \\
\hline & $\omega$ & 0.000001 & 0.0000001 & 6.62 & 0.000 \\
\hline & $\alpha$ & 0.1472 & 0.0106 & 13.89 & 0.000 \\
\hline & $\beta$ & 0.8392 & 0.0099 & 84.06 & 0.000 \\
\hline \multirow{5}{*}{$\mathrm{zn}$} & $\mu$ & 0.0002 & 0.0002 & 0.99 & 0.321 \\
\hline & $\rho$ & -0.0075 & 0.0167 & -0.45 & 0.651 \\
\hline & $\omega$ & 0.0000003 & 0.0000001 & 3.80 & 0.000 \\
\hline & $\alpha$ & 0.1397 & 0.0099 & 14.11 & 0.000 \\
\hline & $\beta$ & 0.8575 & 0.0099 & 85.82 & 0.000 \\
\hline \multirow{5}{*}{ sn } & $\mu$ & 0.0001 & 0.0002 & 0.58 & 0.563 \\
\hline & $\rho$ & -0.0005 & 0.0167 & -0.03 & 0.973 \\
\hline & $\omega$ & 0.0000008 & 0.0000001 & 7.88 & 0.000 \\
\hline & $\alpha$ & 0.1711 & 0.0077 & 22.08 & 0.000 \\
\hline & $\beta$ & 0.8162 & 0.0088 & 91.82 & 0.000 \\
\hline \multirow{5}{*}{ ni } & $\mu$ & 0.0002 & 0.0003 & 0.86 & 0.390 \\
\hline & $\rho$ & -0.0138 & 0.0170 & -0.81 & 0.416 \\
\hline & $\omega$ & 0.00001 & 0.000003 & 3.69 & 0.000 \\
\hline & $\alpha$ & 0.0930 & 0.0085 & 10.85 & 0.000 \\
\hline & $\beta$ & 0.8811 & 0.0133 & 66.24 & 0.000 \\
\hline
\end{tabular}

Note: The model: $R_{t}=\mu+\rho R_{t-1}+\varepsilon_{t}, \quad h_{t}=\omega+\alpha \varepsilon_{t-1}^{2}+\beta h_{t-1}$

The impact results of oil return variable on LME metals returns with GARCH effects report in Table 4. The oil impacts on base metals show positive impact with $1 \%$ statistical significance. For example, a $10 \%$ rise in oil return increases the nickel return of $2.4 \%$. The sum of $\alpha$ and $\beta$ measures the volatility persistent, which indicates to be close to one. This is consistent across metals of the largest 0.9936 of $\mathrm{zn}$ and the lowest $0.9735 \mathrm{of} \mathrm{sn}$. It is found that the fluctuation of oil impacts on statistically significant movement on base metals, even though they are traded at different markets. 
Table 4. Univariate GARCH $(1,1)$ Estimation

\begin{tabular}{|c|c|c|c|c|c|}
\hline & & coefficient & S.E. & z-statistic & p-value \\
\hline \multirow{5}{*}{$\mathrm{cu}$} & $\mu$ & 0.0001 & 0.0002 & 0.87 & 0.382 \\
\hline & $\rho$ & 0.1859 & 0.0095 & 19.55 & 0.000 \\
\hline & $\omega$ & 0.00001 & 0.000001 & 3.61 & 0.000 \\
\hline & $\alpha$ & 0.1171 & 0.0086 & 13.56 & 0.000 \\
\hline & $\beta$ & 0.8635 & 0.0118 & 72.64 & 0.000 \\
\hline \multirow{5}{*}{ al } & $\mu$ & -0.0001 & 0.0001 & -0.45 & 0.651 \\
\hline & $\rho$ & 0.1551 & 0.0082 & 18.76 & 0.000 \\
\hline & $\omega$ & 0.000002 & 0.0001 & 1.51 & 0.132 \\
\hline & $\alpha$ & 0.0685 & 0.0081 & 8.41 & 0.000 \\
\hline & $\beta$ & 0.9202 & 0.0127 & 72.25 & 0.000 \\
\hline \multirow{5}{*}{$\mathrm{pb}$} & $\mu$ & 0.0003 & 0.0002 & 1.28 & 0.199 \\
\hline & $\rho$ & 0.1668 & 0.0112 & 14.82 & 0.000 \\
\hline & $\omega$ & 0.000001 & 0.0000001 & 6.61 & 0.000 \\
\hline & $\alpha$ & 0.1348 & 0.0097 & 13.88 & 0.000 \\
\hline & $\beta$ & 0.8495 & 0.0096 & 87.94 & 0.000 \\
\hline \multirow{5}{*}{$\mathrm{zn}$} & $\mu$ & 0.0002 & 0.0002 & 1.02 & 0.305 \\
\hline & $\rho$ & 0.1496 & 0.0098 & 15.15 & 0.000 \\
\hline & $\omega$ & 0.000001 & 0.000001 & 3.88 & 0.000 \\
\hline & $\alpha$ & 0.1367 & 0.0096 & 14.15 & 0.000 \\
\hline & $\beta$ & 0.8569 & 0.0105 & 81.47 & 0.000 \\
\hline \multirow{5}{*}{ sn } & $\mu$ & 0.0001 & 0.0002 & 0.57 & 0.569 \\
\hline & $\rho$ & 0.1249 & 0.0094 & 13.29 & 0.000 \\
\hline & $\omega$ & 0.00001 & 0.000001 & 9.47 & 0.000 \\
\hline & $\alpha$ & 0.1658 & 0.0077 & 21.48 & 0.000 \\
\hline & $\beta$ & 0.8077 & 0.0097 & 83.22 & 0.000 \\
\hline \multirow{5}{*}{ ni } & $\mu$ & 0.0002 & 0.0003 & 0.63 & 0.531 \\
\hline & $\rho$ & 0.2422 & 0.0141 & 17.13 & 0.000 \\
\hline & $\omega$ & 0.00001 & 0.000001 & 3.10 & 0.002 \\
\hline & $\alpha$ & 0.0859 & 0.0081 & 10.57 & 0.000 \\
\hline & $\beta$ & 0.8927 & 0.0127 & 69.77 & 0.000 \\
\hline
\end{tabular}

Note: The model: $\mathrm{R}_{\mathrm{t}}^{\mathrm{LME}}=\mu+\rho \mathrm{R}_{\mathrm{t}}^{\text {oil }}+\varepsilon_{\mathrm{t}}, \quad \mathrm{h}_{\mathrm{t}}=\omega+\alpha \varepsilon_{\mathrm{t}-1}^{2}+\beta \mathrm{h}_{\mathrm{t}-1}$

While this paper motivation is to model the volatility transmission between oil and base metals returns, it is now to explore the bivariate GARCH model, which reports in Table 5. In case of zinc (zn) the convergence of bivariate GARCH does not achieve, so that this paper reports the empirical results except zinc. It is found that estimated coefficients in the ARCH and GARCH matrices are highly significant and have large magnitudes, which implies volatility persistence once again. This high level of volatility persistence is consistent with early studies using somewhat high frequency data. (Ewing \& Malik, 2013) Both oil and base metals volatilities are significantly affected and volatility in its own market in the previous period, which is consistent with univariate GARCH models. Furthermore, the volatility in either oil or base metals is directly affected by volatility from the other market, which is somewhat strong result against the Ewing \& Malik (2013). Notice that they found that both the gold and oil volatility affected across markets volatilities with consideration of incorporating structural breaks. However, this paper shows highly significant volatility transmission between oil and LME futures return series without any artificial allowing structural break. I believe these results are more robust compared to Ewing \& Malik (2013). Under the finding results, the market shock transmission between oil and LME futures is found. Within the results, the hedging decisions across the oil and LME futures are very useful to deal with market risk, because both commodity markets is affected by news and market shocks in its own market and indirectly affects across markets exist. 
Table 5. Bivariate GARCH $(1,1)$ Estimation

\begin{tabular}{|c|c|c|c|c|c|}
\hline & $\mathrm{cu}$ & al & $\mathrm{pb}$ & $\mathrm{sn}$ & ni \\
\hline $\mathrm{C}(1,1)$ & $7.96 \times 10^{-7}$ & $1.16 \times 10^{-6}$ & $1.37 \times 10^{-6}$ & $1.08 \times 10^{-6}$ & $1.23 \times 10^{-6}$ \\
\hline $\mathrm{C}(1,2)$ & $-9.25 \times 10^{-9}$ & $1.11 \times 10^{-7}$ & $4.53 \times 10^{-8}$ & $3.44 \times 10^{-8}$ & $2.94 \times 10^{-7}$ \\
\hline $\mathrm{C}(2,2)$ & $6.14 \times 10^{-7 *}$ & $6.89 \times 10^{-7 * *}$ & $1.49 \times 10^{-9}$ & $2.05 \times 10^{-8}$ & $4.21 \times 10^{-6 * * *}$ \\
\hline $\mathrm{B}(1,1)$ & $0.9470 * * *$ & $0.9429 * * *$ & $0.9417 * * *$ & $0.9403 * * *$ & $0.9387 * * *$ \\
\hline $\mathrm{B}(1,2)$ & $0.9689 * * *$ & $0.9714 * * *$ & $0.9758 * * *$ & $0.9749 * * *$ & $0.9681 * * *$ \\
\hline $\mathrm{B}(2,2)$ & $0.9485 * * *$ & $0.9558 * * *$ & $0.9605 * * *$ & $0.9503 * * *$ & $0.9457 * * *$ \\
\hline $\mathrm{A}(1,1)$ & $0.0514 * * *$ & $0.0544 * * *$ & $0.0555 * * *$ & $0.0576 * * *$ & $0.0592 * * *$ \\
\hline $\mathrm{A}(1,2)$ & $0.0279 * * *$ & $0.0244 * * *$ & $0.0208 * * *$ & $0.0214 * * *$ & $0.0261 * * *$ \\
\hline $\mathrm{A}(2,2)$ & $0.0486 * * *$ & $0.0400 * * *$ & $0.0393 * * *$ & $0.0521 * * *$ & $0.0461 * * *$ \\
\hline log-likelihood & $21,820.85$ & $22,443.42$ & $21,049.52$ & $21,543.27$ & $20,098.22$ \\
\hline
\end{tabular}

Note: a. $* * *, * *$ and $*$ represent statistical significance levels at $1 \%, 5 \%$ and $10 \%$, respectively.

b. The model: $\mathrm{H}_{\mathrm{t}}=\mathrm{C}^{\prime} \mathrm{C}+\mathrm{B}^{\prime} \mathrm{H}_{\mathrm{t}-1} \mathrm{~B}+\mathrm{A}^{\prime} \varepsilon_{\mathrm{t}-1} \varepsilon_{\mathrm{t}-1}^{\prime} \mathrm{A}$

\section{Summary and Implication}

This study exhibits the volatility transmission from oil futures prices to base metals futures prices to explain the role of uncertainty in commodity futures market. It is found that volatility transmissions between oil and base metals are significant and have similar impacts, which are strong evidence of shock transmission between the oil and base metals. The finding in this study implies that base metal futures market investors may indirectly rely on oil futures market volatility. Under this result, the behavior of volatility in oil and LME futures prices applies to hedging decisions across the commodity markets is useful.

The modeling of volatility prediction to calculate the appropriate valuations of commodity derivatives is important because conditional volatility is highly persistent across the commodity based on the results in this paper. The analysis provides valuable information on risk management in both oil and base metal market to illustrate the importance of time variation model.

Further studies regarding this issue should focus on the checking of possibility of hedge strategy across metal futures markets between base metals and precious metals such as gold, silver, platinum and palladium.

\section{Acknowledgements}

Hyeon Sook Kim, my colleague, provides the data set and gives useful comments.

\section{References}

Batten, J., \& Lucey, B. (2010). Volatility in the gold futures market, Applied Economics Letters, 17, 187-190. https://doi.org/10.1080/13504850701719991

Bollerslev, T., \& Wooldriged, J. M. (1992). Quasi-maximum likelihood estimation and inference in dynamic models with time-varing covariance, Econometric Review, 11, 143-172. https://doi.org/10.1080/07474939208800229

Cheng, I., \& Xiong, W. (2014). Financialization of commodity markets, Annual Review of Financial Economics, 6, 419-441. https://doi.org/10.1146/annurev-financial-110613-034432

Ewing, B., \& Malik, F. (2010). Estimating volatility persistence in oil prices under structural breaks, Financial Review, 45, 1011-1023. https://doi.org/10.1111/j.1540-6288.2010.00283.x

Ewing, B., \& Malik, F. (2013). Volatility transmission between gold and oil futures under structural breaks, International Review of Economics and Finance, 25, 113-121. https://doi.org/10.1016/j.iref.2012.06.008

Figuerrola, F. I., \& Gilbert, C. (2008). Commonality in the LME aluminum and copper volatility processes through a FIGARCH lens, Journal of Futures Markets, 28, 935-962. https://doi.org/10.1002/fut.20338

Haigh, M., \& Holt, M. (2002). Crack spread hedging: Accounting for time-varying volatility spillovers in the energy futures markets, Journal of Applied Econometrics, 17, 269-289. https://doi.org/10.1002/jae.628

Hammoudeh, S., \& Yuan, Y. (2008). Metal volatility in presence of oil and interest rate shocks, Energy Economics, 30, 606-620. https://doi.org/10.1016/j.eneco.2007.09.004

Hooker, M. (2002). Are oil shocks inflationary? Asymmetric and nonlinear specification versus changes in regime, Journal of Money, Credit, and Banking, 34, 540-561. https://doi.org/10.1353/mcb.2002.0041

Malik, F., \& Hammoudeh, S. (2007). Shock and volatility transmission in the oil, US and Gulf equity markets, International Review of Economics and Finance, 16, 357-368. https://doi.org/10.1016/j.iref.2005.05.005

Park, J., \& Lim, B. (2018). Testing Efficiency of the London Metal Exchange: New Evidence, working paper. 
Ratti, R., \& Vespignani, J. (2013). Why are crude oil prices high when global activity is weak? Economics Letters, 121, 133-136. https://doi.org/10.1016/j.econlet.2013.07.002

Silvennoinen, A., \& Thorp, S. (2013). Financialization, crisis and commodity correlation dynamics, Journal of International Financial Markets, Institutions and Money, 24, 42-65. https://doi.org/10.1016/j.intfin.2012.11.007

Tang, K., \& Xiong, W. (2012). Index investment and the financialization of commodities, Financial Analysts Journal, 68, 54-74. https://doi.org/10.2469/faj.v68.n6.5

Wu, F., Guan, Z., \& Myers, R. J. (2011). Volatility spillover effects and cross hedging in corn and crude oil futures, Journal of Futures Markets, 31, 1052-1075. https://doi.org/10.1002/fut.20499

\section{Copyrights}

Copyright for this article is retained by the author(s), with first publication rights granted to the journal.

This is an open-access article distributed under the terms and conditions of the Creative Commons Attribution license which permits unrestricted use, distribution, and reproduction in any medium, provided the original work is properly cited. 